\title{
The Memory of the Cambodian Genocide: The Tuol Sleng Genocide Museum
}

\author{
Abstract \\ This article examines the representation of the memory of the Cambodian genocide \\ in the Tuol Sleng Genocide Museum in Phnom Penh. The museum is housed in the \\ former Tuol Sleng prison, a detention and torture centre through which thousands of \\ people passed before execution at the Choeung Ek killing field. From its opening in \\ 1980, the museum was a stake in the ongoing conflict between the new Vietnamese- \\ backed government and Pol Pot's Khmer Rouge guerrillas. Its focus on encouraging \\ an emotional response from visitors, rather than on pedagogy, was part of the \\ museum's attempt to engender public sympathy for the regime. Furthermore, in \\ order to absolve former Khmer Rouge members in government of blame, the \\ museum sort to attribute responsibility for the atrocities of the period to a handful of \\ 'criminals'. The article traces the development of the museum and its exhibitions up \\ to the present, commenting on what this public representation of the past reveals \\ about the memory of the genocide and the changing political situation in Cambodia.
}


The Tuol Sleng prison (also known by its codename S-21) was the largest centre for torture during the rule of the Cambodian Khmer Rouge (KR) between 1975 and 1979. Prisoners were interrogated at Tuol Sleng before being taken to the Choeung Ek killing field located fifteen kilometres southwest of Phnom Penh. Approximately 20,000 people are believed to have been executed and buried at this site. ${ }^{1}$ In the wake of the Vietnamese invasion in 1979, two photojournalists discovered Tuol Sleng. Quickly labelled the 'Asian Auschwitz', the prison proved useful to the new People's Republic of Kampuchea (PRK) in its attempt to undermine the legitimacy of Pol Pot's KR guerrillas in the ongoing civil war. The site was quickly transformed into a museum devoted to genocide. ${ }^{1}$

The role that Tuol Sleng has played in the national narrative constructed around the period of KR rule has provoked controversy. David Chandler has argued that Tuol Sleng was developed into a museum specifically to 'induce and cultivate collective negative memories' toward the former regime. ${ }^{1}$ James $A$. Tyler et al claim that the museum was integral to the PRK's efforts to memorialise the genocide in such a way as to reinforce the legitimacy of the new government. ${ }^{1}$ Such concerns were central to the creation of the Tuol Sleng Genocide Museum and embedded in the experience of visiting. Tuol Sleng thus became, according to Judy Ledgerwood, an important site not only in the construction of the collective memory of the genocide but also in the building of a new Cambodian national history. ${ }^{1}$

Tuol Sleng was discovered on 8 January 1979, the day after Vietnamese forces entered Phnom Penh and toppled the KR. The following month, Vietnamese Colonel Mai Lam arrived in the capital with a view to inspecting the prison. Mai Lam was 
fundamental to the transformation of the site from a prison into a museum to document the genocidal crimes of KR leaders. He had previously designed the Museum of American War Crimes in Ho Chi Minh City and had visited Poland to study the Auschwitz-Birkenau State Museum. In designing the Tuol Sleng museum, Mai Lam sought to draw attention to KR crimes as a means of legitimising Vietnam's invasion of Cambodia in 1979. ${ }^{1}$ Against international criticism, the Vietnamese were keen to reject any notion that the invasion was for territorial or political gain, presenting themselves 'not only as Cambodia's recent saviour but also its long-time friend'. ${ }^{1}$ Consequently, the horrors depicted at S-21 apparently justified the invasion as a humanitarian mission, 'transforming [the Vietnamese] from foreign invaders into liberators' ${ }^{1}$

According to Chandler, a second concern motivated Mai Lam: the search for evidence for the upcoming trials of those that the PRK deemed responsible for the atrocities. ${ }^{1}$ The communist PRK sought to draw a distinction between 'legitimate' communism practiced by the Vietnamese and perverted, even fascist KR-style communism. ${ }^{1}$ The Tuol Sleng museum thus communicated a narrative in which the genocide arose from a few 'murderous criminals' who had hijacked the revolution in 1975, killing the true revolutionaries; these few became known as the 'Pol Pot - leng Sary genocidal clique'. S-21 was therefore designed to depict a genocide rather than the murder of political enemies as had happened in other communist regimes. To lay the blame on a small group of KR leaders focused and personalised the responsibility for the events, directing attention away from the fact many PRK leaders were former KR who had defected to Vietnam between 1977 and $1978 .{ }^{1}$ This allocation of responsibility to a handful of KR leaders continues to be a central feature of the museum. 
During 1979-80 Tuol Sleng became a stake in the developing propaganda war between the guerrilla KR and the Vietnamese-backed PRK. Indeed in the year following its discovery, only foreign journalists were admitted entry, accompanied by guides throughout their visit. ${ }^{1}$ With a view to ending US and Chinese support for the KR, a 1980 PRK Ministry of Culture, Information, and Propaganda document asserted that the museum would 'show the international guests the cruel torture committed by the traitors to the Khmer people'. ${ }^{1}$ To further undermine the KR in the eyes of a Western audience, the museum presented its evidence in ways similar to those of museums of the Holocaust: heaps of ragged clothing on display in glass cabinets, the preservation of torture devices, rooms full of victims' photographs and the exhibition of mass graves. Serge Thion has commented upon the 'sinister charisma of Auschwitz' that is present throughout Tuol Sleng. ${ }^{1}$ This is unsurprising: Paul Williams speculates that Mai Lam collaborated with East German memorial specialists specifically to introduce Holocaust imagery into Tuol Sleng, a deliberate attempt to draw parallels between the KR and the Nazi regimes. ${ }^{1}$

The doors of the Tuol Sleng museum opened to the public on 13 July 1980. The PRK government encouraged Cambodians from all regions of the country to visit the site and in the first month alone a total of 19,060 Cambodians made the trip. ${ }^{1}$ Mai Lam's express desire was to evoke an emotional response from visitors. ${ }^{1}$ The experience of visiting the museum is harrowing. The site consists of four threestorey buildings. Building $A$, a former torture unit, contains rusted metal bedsteads, shackles, spears, spikes and other metal torture devices. Within each room, a large photograph shows a blood-soaked corpse. Building B houses thousands of prisoner 'mug-shots' that were taken as the victims arrived at the prison. ${ }^{1}$ From a distance, the black and white photos do little more than suggest the high number of 
Cambodians who were incarcerated in the prison. Upon closer inspection, the visitor grasps the individuality of the victims in the variety of facial expressions: 'a frown, a smirk, bewilderment, anger, shock, withdrawal, fear, most often fear'. ${ }^{1}$ Within this building, too, is an archive containing thousands of the written 'confessions' of former inmates.

The third building, which remains in an allegedly untouched condition, houses small individual cells some of which have faded blood stains on the floor. There are no restrictions as to where the visitor can wander, enabling her to enter the cells and close the timeworn doors. The last building of the complex, building D, contains artefacts from the torture centre such as the chair used by prisoners during photographing. Examples of torture devices are on display in glass cases, accompanied by 'garishly coloured' paintings on the walls to illustrate their use. ${ }^{1}$ These paintings are the work of one of the prison's few survivors, Vann Nath (19462011) who was commissioned in the 1980 s by the government to capture 'on canvas the horrendous torture and excruciating suffering' experienced within the prison walls. ${ }^{1}$ Tuol Sleng's representation of a 'frozen past' has led Patrizia Violi to consider it a trauma site, rather than simply a museum. As such, it does not merely provide historic information but, more evocatively, remains in existence as a factual and material testimony to the violence that occurred there. ${ }^{1}$

Throughout the 1980s and 1990s, many visitors commented upon the lack of written information on display. Yet the paucity was integral to the museum's use as a means of affective propaganda. ${ }^{1}$ As Ledgerwood has shown, where information does appear it is presented in Khmer, French, and English but not all texts appeared in the three languages. ${ }^{1}$ Rachel Hughes notes that many visitors left the museum without a sense of having learned about the regime. However, they nevertheless 
regarded the experience as a significant act of testimony in a larger humanitarian tourism. ${ }^{1}$ Indeed despite the dearth of pedagogical material in the museum, comments left in visitor books nevertheless attest to the fact that many tourists left the museum under the impression that they had discovered what 'really' happened in Cambodia. $^{1}$

The museum reflects the continuing political instability in Cambodia of the late twentieth century. Until its dismantling in 2002, the most disturbing aspect of the museum was the decaying 'Skull Map'. A personal design of Mai Lam and the 'emotional climax of the tour', this was a twelve metre square map pieced together from over 300 exhumed skulls and human bones formed into the shape of Cambodia. Red paint marked the Tonlé Sap Lake and the Mekong and Tonlé Sap rivers. The map proved hugely controversial. The use of human skulls contravened the Buddhist principle of cremation, leading some Cambodians to consider it dehumanising, rather than as a memorial to the victims of the regime. ${ }^{1}$ Cambodian King Norodom Sihanouk himself claimed that the map was disrespectful to those killed, stating '[i]t's like hanging people twice'. ${ }^{1}$ On the other hand, the PRK government claimed that the Skull Map was paramount to the preservation of the memory of the malevolence of the KR. As such it would educate future generations in the suffering inflicted upon Cambodia. ${ }^{1}$ Following the map's removal from the wall, the skulls are now housed in a wooden case enclosed by glass and hidden from view. ${ }^{1}$ Still, the fact that the skulls remain on site is emblematic of the museum's function as a form of propaganda in which the use of physical evidence to evoke an emotional response was considered to be more influential than textual commentary.

The 'mug shots' of the prison's former inmates on display in building B have proved another bone of contention. Within the first two years following liberation, 
many Cambodians in search of missing relatives came to view the photographs. If recognised, the individual's name was inscribed onto the photograph. Hughes notes that this was an act of personal and public remembrance: 'To name and thereby individuate one of the anonymous mass of S-21 victims was also to symbolically reject the inhumane treatment perpetrated en masse by the S-21 authorities'. 1 However, the museum disallowed the practice to avoid damaging the photographic evidence. Furthermore, as Hughes has argued, leaving the photographs nameless was consonant with the museum's narrative of collective rather than individual suffering. ${ }^{1}$

There is another reason for leaving the photographs nameless to consider. As KR rule crumbled and paranoia grew, the majority of those who perished at Tuol Sleng were former regime cadre who stood accused of being enemies of the state; Nuon Chea, second-in-command to Pol Pot, remarked in the latter years of the regime, 'We worry most of all about the enemy inside'. ${ }^{1}$ The 'enemy inside' thus features in many of these photographs and to identify an individual could also mean naming a former member of the KR. ${ }^{1}$ This fact was recognised in a 1981 Washington Post article: 'Most of the photographs dating from the bloodiest months of the regime in 1978 are of Khmer Rouge soldiers, cadres, provincial officials and even Tuol Sleng guards and interrogators arrested on suspicion of being traitors or CIA agents'. ${ }^{1}$ Throughout the 1980 s, the museum did little to enlighten visitors of this fact, desiring both to simplify the complicated memory of the KR and promote the hatred of the Pol Pot clique.

From the moment of its discovery, the PRK exploited Tuol Sleng in the propaganda war against the KR. Initially an endeavour to legitimise the Vietnamese invasion to the world, throughout the 1980s and early 1990s the museum continued 
to serve as a reminder of the atrocities of the KR regime. Aspects of Tuol Sleng are certainly reminiscent of Auschwitz, revealing the government's desire to construct a genocide on an equal footing with the Holocaust. The stylistic devices used to 'westernise' Tuol Sleng have been termed 'cues to connect' by Shannon Davis and Jacky Bowring, meaning '... those design strategies or site features... that (either consciously or unconsciously) engage Western visitors by placing the "distant" or the "less familiar" history expressed at these sites within pre-understood and culturally acceptable "Western" frames'. ${ }^{1}$ Such Western frames of understanding provided visitors with the opportunity to draw connections between the European and Cambodian genocide sites.

II

In 1998 the KR finally ceased to threaten the prospect of peace in Cambodia. That same year, the former leader of the regime, Pol Pot, died from natural causes while still living freely in the Cambodian jungle. To some extent, these circumstances were received quite differently in Cambodia. On the one hand, Prime Minister Hun Sen offered amnesty to two former KR leaders, 'Brother Number Two' Nuon Chea and the former Head of State leng Sary. ${ }^{1}$ Hun Sen asserted that the two should be welcomed back into society not 'with handcuffs but with a bouquet of flowers'. ${ }^{1}$ Chandler argues that as far as Hun Sen was concerned 'the Khmer Rouge period, by coming to an end, was no longer a political issue and was therefore devoid of interest'. ${ }^{1}$ This policy of 'collective amnesia' - as termed by Chandler was epitomised in the Prime Minister's 1998 appeal 'to dig a hole and bury the past'. ${ }^{1}$ It should be noted here that that the pressure to develop an international body to try the former KR leaders developed largely outside Cambodia. ${ }^{1}$ On the other 
hand, the death of the KR and its leader not only led to renewed calls for the surviving KR leaders to be brought to justice but it saw survivors recount their experiences on an unprecedented scale through the medium of literature and film. There was thus a discrepancy between the silence desired by the regime and the flourishing of Cambodian memory. ${ }^{1}$

This discrepancy is somewhat visible throughout Tuol Sleng. As the Extraordinary Chambers in the Courts of Cambodia (ECCC) gathered evidence for its legal proceedings, new information was added to the museum, some of which contradicted the information already on display. The present-day visitor may observe, for example, inconsistency in the stated number of survivors from Tuol Sleng. Building D contains a photograph of seven people who in 1979 were believed to be the only survivors of the torture centre. However, an information board added in 2011 displaying general information regarding the prison provides a different number: there were as many as 179 survivors. However, no names are provided and the original seven continue to be widely recognised and celebrated.

Tuol Sleng came to the fore during the first trial of a KR leader. Case 001 at the ECCC was the first official trial prosecuting a former KR leader for involvement in the events of 1975-79. The defendant, Kaing Guek Eav, alias Duch, was the former head of the S-21 security centre. ${ }^{1}$ Nic Dunlop and Nate Thayer were the first to locate and interview Duch in 1999, after which Dunlop referred to him as the 'technician' of Cambodia's holocaust. ${ }^{1}$ Duch has further been labelled "Cambodia's Heinrich Himmler'. 1 The Cambodian government had long been aware of Duch's location but 'apparently made a political decision not to arrest him'. ${ }^{1}$ Such a decision was in line with Hun Sen's appeal to move on from the past. ${ }^{1}$ The fact that the mastermind of the notorious Tuol Sleng prison was the first to be charged served to 
illustrate the continued importance of the site to the memory of the genocide. The survivors of S-21 appeared as witnesses in the case against Duch. ${ }^{1}$ In 2008 Duch revisited Tuol Sleng and Choeung Ek to reconstruct his actions for the tribunal, further demonstrating the museum's centrality to the collective memory of the

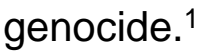

Duch's status as a pivotal figure in the genocide - 'the direct link between the Khmer Rouge political leadership and its killing machine' - is evident throughout the Tuol Sleng museum. ${ }^{1}$ Large information boards concerning his crimes and the criminal proceedings against him have been added to a room in building D. Also included were signs with lengthy definitions of 'genocide', 'crimes against humanity' and 'war crimes' in order to enable visitors to place the KR crimes within their global legal context; these additions appear only in English. Documentation from Case 002, concerning a further four senior leaders of the KR (Nuon Chea, Khieu Samphan, leng Sary, and the only woman to be tried, leng Thirith), is also on display within this building. ${ }^{1}$ Translations of incriminating handwritten letters are displayed as evidence. One such letter sent by Comrade Soy to Duch in January 1977 asks for assistance in dealing with a comrade who has committed 'traitorous acts'.

Information boards presenting exerts from recent publications have been added to the museum. They include photographs and biographies in both English and Khmer of former cadre of Tuol Sleng. These former leaders are depicted as 'a group of children [aged between 12 and 18] who became victims of the Khmer Rouge regime'. ${ }^{1}$ The visitor learns that the comrades were only children at the time of recruitment, rendering them 'easily trained owing to their innocence'; they, too, are considered 'victims of the revolution'. ${ }^{1}$ Added to the museum in 2002, this narrative reinforces the museums message that only senior leaders of the KR should be held 
accountable for genocide. However, it also reflects the growing freedom of historians and survivors to confront less addressed aspects of these years.

In April 2008, the Documentation Center of Cambodia, an independent research institute, launched the 'Reflections: Democratic Kampuchea and Beyond' exhibition. Housed in three of the museum's four buildings the exhibition aims 'to take visitors on an historical-visual journey', from the first day of KR rule in 1975 to the present day. ${ }^{1}$ This exhibition confronts past criticism of the museum's lack of information by providing historical context to the KR regime, while also seeking to answer the fundamental questions concerning its motives at Tuol Sleng. ${ }^{1}$ Part of the exhibition shows scanned confessions from former inmates, enlarged and displayed in both Khmer and in English. According to Phnom Penh Post journalist, Elena Lesley, 'Reflections provides a solid explanation of the Khmer Rouge's rise to power, ideology, and eventual fall. Those already well-versed in the Khmer Rouge story will appreciate the rare artefacts on display and details about life under [the regime]'. ${ }^{1}$ Such additions to the museum are indicative of the growing sense of freedom enjoyed by victims and perpetrators alike to discuss their experiences, a freedom that was ultimately promoted by the tribunal proceedings since 2006 .

The efforts to provide greater historical contextualisation to the genocide have influenced the development of Choeung Ek too. This former killing field had been the target of criticisms similar to those of Tuol Sleng: it contained little information about the KR and ignored the individual experience of victims. ${ }^{1}$ Recent research has endeavoured to identify those who perished at the site and some graves now bear information about the victim buried there. Critics had claimed that, like Tuol Sleng, the site at Choeung Ek placed too much emphasis on the crimes of the Pol Pot 'clique', described on one information panel as men in 'human form but their hearts 
[were] demon's hearts'. ${ }^{1}$ Since 2011, each visitor, through means of a headset, has had access to an audio tour of the entire site. It includes survivor testimonies drawn from different periods between 1975 and 1979, thus providing an insight into life under the KR government. ${ }^{1}$ A chilling account by former executioner, Him Huy, of some techniques used to kill prisoners provides visitors with the perpetrators viewpoint. Nevertheless, the opening passage of the guide describes the first day of $\mathrm{KR}$ rule as one on which 'the fanatical leader Pol Pot destroyed our world and replaced it with his deranged vision of a 'pure' communist society', thus reinforcing the traditional narrative of blame as depicted within Tuol Sleng. ${ }^{1}$ The affective experience remains present, too. The tour reminds visitors that their route from Tuol Sleng to Choeung Ek will mirror that taken by the victims decades earlier. Nevertheless, it is undeniable that the centre has taken steps to educate visitors and the audio tour is available in several languages. ${ }^{1}$ The end of the tour reminds visitors of the duty to remember the Killing Fields: 'For your sake, remember us - and remember our past as you look to your future'. ${ }^{1}$

III

From 1979, the Vietnamese-backed PRK desired to showcase KR atrocities to the world at the Tuol Sleng site. From the appointment of a specialist in the creation of memorial museums as director of the museum and the initial preference given to international visitors, to the focus on visual evidence of the KR genocide, the PRK attempted to control the way in which the genocide was represented and remembered both by the Cambodian population and the international community.. The controversial 'Skull Map' epitomised this preference for visual representation and affective response. The drawing of parallels with the Holocaust further 
suggested an attempt to depict the atrocity as equal to that of the Nazi genocide. Indeed Tuol Sleng's use of a 'frozen-past' technique in order to provide evidence of KR crimes may be understood with reference to James Young's work on memorialisation at Auschwitz and Majdanek. Young writes that memorials of this kind are devastating in their impact: in contrast to 'memorials located away from the sites of destruction, the remnants here tend to collapse the distinction between themselves and what they evoke'. ${ }^{1}$ Thus, they do not merely gesture towards past events, but suggest themselves as fragments of events, which according to Young, compel the visitor 'to accept the horrible fact that what they show is real'. ${ }^{1}$ Tuol Sleng's focus on the visual is effective in traversing conventional cultural and linguistic boundaries; the presentation of skulls, bones and clothing are customary objects recognised by all human civilisations. ${ }^{1}$ This orientation around visual evidence leaves little scope for individual interpretation of the museum, signifying that 'the genocide memoryscape of Cambodia is a clear illustration of instructive didactic representation memory'. ${ }^{1}$ The Tuol Sleng museum thus represents not only a site of memory but an example of how the state can intervene in the public representation of the past in order to construct a collective history upon which to build the present.

\section{Works Cited}


Bowring, J., and Davis, S., 'Connecting with Tragedy Through Landscapes of Memory: Memorial Design, Tourism, and the Post-Genocide Memoryscapes of Cambodia, Rwanda, and Germany', Memory Connection, 1/1 (2011): 377-391. Branigan, W., 'Khmer Prison Still Haunts Nation: Khmer Prison Recalls Cambodian Nightmare', The Washington Post, 12 Aug. 1981.

Campbell, C., 'The Bitter Legacy of Pol Pot Weighs on Cambodia', The New York Times, 5 Apr. 1983.

Caswell, M., Archiving the Unspeakable: Silence, Memory and the Photographic Record in Cambodia (Madison, WI: University of Wisconsin Press, 2014).

Chandler, D., Voices from S-21: Terror and History in Pol Pot's Secret Prison, (California: University of California Press, 1999).

Chandler, D., 'Cambodia Deals with its Past: Collective Memory, Demonisation and Induced Amnesia', Totalitarian Movements and Political Regimes, 9/2-3 (2008): 355369.

Chandler, D., 'Case Study: The S-21 Project', 2014, http://www.massviolence.org/The-S-21-Project

Cougill, W., 'Buddhist Cremation Traditions for the Dead and the Need to Preserve Forensic Evidence in Cambodia', n.d.,

\section{http://www.d.dccam.org/Projects/Maps/Buddhist_Cremation_Traditions.htm}

Dunlop, N., and Thayer, N., 'Duch Confesses', Far Eastern Economic Review, 170/3 (1999): 76

Dunlop, D., 'On the Trail of Pol Pot's Chief Executioner', Prospect, 20 Aug. 2002.

Ea, M.-T., and Sim, S., Victims and Perpetrators? Testimony of Young Khmer Rouge Comrades, (Phnom Penh: Documentation Centre of Cambodia, 2001).

Fawthrop, T., 'Vann Nath obituary', The Guardian, 5 Sept. 2011. 
Fournet, C., The Crime of Destruction and the Law of Genocide: Their Impact on Collective Memory (Aldershot: Ashgate, 2007).

Gittings, J., 'Pol Pot Men Say Sorry for Killing Fields', The Guardian, 30 Dec. 1998. Ham S., and Myers, B., 'Tuol Sleng Workers Dismantle Skull Map', Cambodia Daily, 11 Mar. 2002.

Hughes, R., 'Dutiful Tourism: Encountering the Cambodian Genocide', Asia Pacific Viewpoint, 49/3 (2008): 318-330.

Johnson K., and Kimsan, C., 'No Trial for Defectors, Hun Sen Asserts', The Cambodia Daily, 5 May 2014.

'Khmer Rouge Leader “Enacts Role”', BBC News, 26 Feb. 2008.

Ledgerwood, J., 'The Cambodian Tuol Sleng Museum of Genocidal Crimes: National Narrative,' in D. E. Lorey and W. H. Beezley (eds.), Genocide, Collective Violence, and Popular Memory: The Politics of Remembrance in the Twentieth Century (Wilmington: Scholarly Resources Inc., 2002): 103-122.

Lesley, E., 'Reflections on Democratic Kampuchea', The Phnom Penh Post, 12 Jun. 2008.

Maguire, P., Facing Death in Cambodia (New York; Chichester: Columbia University Press, 2005).

Manning, P., 'Governing Memory: Justice, Reconciliation and Outreach at the Extraordinary Chambers in the Courts of Cambodia', Memory Studies, 5/2 (2012): 165-181.

Munthit, K., 'Cambodia's 'skull map' memorial comes down', The Seattle Times, 11 Mar. 2002.

Mydans, S., 'Cambodian Leader Resists Punishing Top Khmer Rouge', The New York Times, 29 Dec. 1998. 
Pellizzari, P., 'Kang Khek leu: "They all had to be eliminated”', The Independent, 11 Feb. 2008.

Sion, B., 'Conflicting Sites of Memory in Post-Genocide Cambodia', Humanity, 2/1 (2011): 1-13.

Thion, S., Watching Cambodia, (Bangkok: White Lotus Co. Ltd, 1993).

'Tuol Sleng's Skull Map to Come Down, be Replaced by Stupa', Cambodia Daily, 9 Mar. 2002.

Tyner, J. A., Brindis Alvarez, G., and Colucci, A. R., 'Memory and the Everyday Landscape of Violence in Post-Genocide Cambodia', Social \& Cultural Geography, 13/8 (2012): 853-871.

Violi, P., 'Trauma Site Museums and the Politics of Memory: Tuol Sleng, Villa Grimaldi and the Bologna Ustica Museum', Theory, Culture \& Society, 29 (2012): 36-75.

Wilkins, G., 'Artist recounts S-21 Ordeal', Phnom Penh Post, 30 Jun. 2009.

Williams, P., 'Witnessing Genocide: Vigilance and Remembrance at Tuol Sleng and Choeung Ek', Holocaust and Genocide Studies, 18/2 (2004): 234-254.

Williams, P., Memorial Museums: The Global Rush to Commemorate Atrocities, (Oxford: Berg, 2007).

Young, J. E., 'The Texture of Meaning: Holocaust Memorials and Meaning', in M. Rossington and A. Whitehead, Theories of Memory: A Reader, (Baltimore: The John Hopkins University Press, 2007): 177-184.

\footnotetext{
${ }^{1}$ Cougill, 'Buddhist Cremation Traditions for the Dead'.

${ }^{1}$ Manning, 'Governing Memory', 5.

${ }^{1}$ Chandler, 'The S-21 Project'.
} 
${ }^{1}$ Tyner et al., 'Memory and the Everyday Landscape of Violence', 853-871.

1 Ledgerwood, 'The Cambodian Tuol Sleng Museum', 116.

${ }^{1}$ Maguire, Facing Death in Cambodia, 91.

${ }^{1}$ Campbell, 'The Bitter Legacy of Pol Pot', 2.

1 Violi, 'Trauma Site Museums', 46.

${ }^{1}$ Chandler, 'Cambodia Deals with its Past', 361.

1 Williams, 'Witnessing Genocide', 248.

${ }^{1}$ Ledgerwood, 'The Cambodian Tuol Sleng Museum', 111 and Chandler, Voices from S-21, 9.

${ }^{1}$ Chandler, Voices from S-21, 10.

1 Ledgerwood, 'The Cambodian Tuol Sleng Museum', 108.

1 Thion, Watching Cambodia, 182.

1 Williams, 'Witnessing Genocide', 248.

${ }^{1}$ Ledgerwood, 'The Cambodian Tuol Sleng Museum', 108.

${ }^{1}$ Chandler, Voices from S-21, 8-9.

${ }^{1}$ Hughes, 'Nationalism and Memory', 182.

${ }^{1}$ Ledgerwood, 'The Cambodian Tuol Sleng Museum,' 105. For a recent examination of photographs and the Cambodian genocide see Caswell, Archiving the Unspeakable.

${ }^{1}$ Ledgerwood, 'The Cambodian Tuol Sleng Museum', 106.

1 Fawthrop, 'Vann Nath obituary'.

1 Violi, 'Trauma Site Museums', 46.

${ }^{1}$ Hughes, 'Nationalism and Memory', 184.

1 Ledgerwood, 'The Cambodian Tuol Sleng Museum', 117.

${ }^{1}$ Hughes, 'Dutiful tourism', 325. 
${ }^{1}$ Ledgerwood, 'The Cambodian Tuol Sleng Museum', 110.

1 'Tuol Sleng's Skull Map to Come Down'.

${ }^{1}$ Ham et al. 'Tuol Sleng Workers Dismantle Skull Map'.

${ }^{1}$ Munthit, 'Cambodia's 'Skull Map' Memorial Comes Down’.

${ }^{1}$ Cougill, 'Buddhist Cremation Traditions for the Dead'.

${ }^{1}$ Hughes, 'Nationalism and Memory', 183.

${ }^{1}$ Hughes, 'Nationalism and Memory', 183.

${ }^{1}$ Chandler, Voices from S-21, 44.

${ }^{1}$ Hughes, 'Nationalism and Memory', 183.

${ }^{1}$ Branigan, 'Khmer Prison Still Haunts Nation'.

${ }^{1}$ Davis et al. 'Connecting with Tragedy', 385-386.

1 'Case 002', http://www.eccc.gov.kh/en/case/topic/2

${ }^{1}$ Gittings, 'Pol Pot Men Say Sorry for Killing Fields'.

${ }^{1}$ Chandler, 'Cambodia Deals with its Past', 356.

${ }^{1}$ Mydans, 'Cambodian Leader Resists Punishing Top Khmer Rouge'.

${ }^{1}$ Chandler, 'Cambodia Deals with its Past', 364.

${ }^{1}$ Chandler, 'Cambodia Deals with its Past', 357.

1 'Case 001', http://www.eccc.gov.kh/en/case/topic/1

${ }^{1}$ Dunlop, 'On the Trail of Pol Pot's Chief Executioner'.

1 Pellizzari, 'Kang Khek leu'.

${ }^{1}$ Dunlop et al. 'Duch Confesses, 76.

1 Johnson et al. 'No Trial for Defectors'.

1 Wilkins, 'Artist Recounts S-21 Ordeal'.

1 'Khmer Rouge Leader "Enacts Role”'.

${ }^{1}$ Dunlop et al. 'Duch Confesses', 78. 
1 ' Case 002', http://www.eccc.gov.kh/en/case/topic/2

${ }^{1}$ Sign at Tuol Sleng Museum of Genocide Crimes, Phnom Penh, September 2013.

${ }^{1}$ M. -T. Ea et al. Victims and Perpetrators?, 12-13.

${ }^{1}$ This quotation is from an information board at the start of the exhibit, September 2013.

${ }^{1}$ Lesley, 'Reflections'.

${ }^{1}$ Lesley, 'Reflections'.

${ }^{1}$ This was argued as late as 2009; see Sion, 'Conflicting Sites of Memory', 7.

1 Sion, 'Conflicting Sites of Memory', 7-8.

${ }^{1}$ Choeung Ek Genocidal Centre leaflet for audio tour, 2011.

${ }^{1}$ Choeung Ek Genocidal Center, 'The Killing Fields', 2

1 The Lonely Planet Travel Guide, http://www.lonelyplanet.com/cambodia/phnompenh/sights/museums-galleries/killing-fields-choeung-ek

${ }^{1}$ Choeung Ek Genocidal Center, 'The Killing Fields', 37.

1 Young, The Texture of Memory, 120-121.

1 Young, The Texture of Memory, 120-121.

${ }^{1}$ Davis et al. 'Connecting with Tragedy', 387.

${ }^{1}$ Davis et al. 'Connecting with Tragedy', 383. 